\title{
Determination and Prevalence of Antinuclear Antibody (ANA) Patterns in Autoimmune Disorders in a Tertiary Care Hospital, Jaipur
}

\author{
Vinita Choudhary ${ }^{1}$, Ayushi Sharma ${ }^{2}$, Vinod Kumar Sharma ${ }^{3}$, \\ Pushpendra Saraswat $^{4}$, Chetan Choudhary ${ }^{5}$ \\ ${ }^{1}$ Asst. Professor; Dept. of Microbiology, MGUMST, Jaipur \\ ${ }^{2,3}$ Demonstrator; Dept. of Microbiology, MGUMST, Jaipur \\ ${ }^{4}$ Lab Director; Central Research Laboratory, MGUMST, Jaipur \\ ${ }^{5}$ Asst. Professor; Emergency Medicine, MGUMST, Jaipur \\ Corresponding Author: Ayushi Sharma
}

DOI: https://doi.org/10.52403/gijhsr.20220104

\begin{abstract}
Introduction: Autoimmunity is the immune response of antibodies against normal cellular components. With the advent of serological testing for autoimmune disorders, detection of anti-nuclear antibodies (ANA) by indirect immunofluorescence method became the gold standard. ANA screening is non-specific, reliable and a quick way and identifies immunofluorescent patterns linked to autoimmune disorders.
\end{abstract}

Aim: This study was undertaken to identify the prevalence of ANA patterns amongst the various demo graph presented in a tertiary care hospital in Jaipur, Rajasthan.

Material and Method: 100 serum samples were screened by indirect immunofluorescence microscopy in the duration of July 2021 to October 2021.

Results: $27 \%$ of the serum samples presented with positive ANA patterns out of which $62.96 \%$ were nuclear speckled, followed by $22.22 \%$ of nuclear homogenous pattern and $7.40 \%$ were observed to be cytoplasmic speckled. The age bracket with higher positivity were $20-40$ years $(28 \%)$ and $40-60(28 \%)$. There was female predominance noted in the ANA positivity.

Conclusion: Nuclear speckled was the most frequent pattern, few unusual patterns were also observed. An observational study is needed to understand not only the epidemiology of autoimmune disorders but also the predictive value of ANA IIF in clinical setup, besides considering the possibility of taking up IIF as a screening tool for autoimmune disorders.

Keywords: Antinuclear antibody (ANA), indirect immunofluorescence (IIF), systemic lupus erythematosus (SLE), autoantibody

\section{INTRODUCTION}

The detection of autoantibodies against intracellular antigens, called antinuclear antibodies (ANAs)has proven to be significant in the screening, diagnosis and measurement of systemic autoimmune rheumatic diseases (SARDs) such as systemic lupus erythematosus (SLE), Sjögren's syndrome ( $\mathrm{SjS})$, mixed connective tissue disease (MCTD), systemic sclerosis (SSc), and idiopathic inflammatory myopathies (IIMs ${ }^{\text {) }}$ []

The preferred technique is indirect immunofluorescence (IIF) with HEp-2 as an antigen source which originates from human epithelial larynx cancer. These cells have a relatively large nucleus and smaller cytoplasm that aids in optimal detection of patterns. The popularity of this technique is explained by the simple and strong test procedure and the modest cost of materials. However, reading the slides is timeconsuming, and the validity of the results depends largely on the skill and knowledge of the microscopist. ${ }^{[2]}$ 
When a patient presents with clinical manifestations with a suspicion of autoimmune condition, the first test advised is antinuclear antibody screening (ANA) that serves as the serological hallmark of autoimmunity. The ANA attacks selfproteins within cell nucleus structures, that now encompass nuclear envelope components, mitotic spindle apparatus, cytosol, cytoplasmic organelles, and cell membranes. Their presence in serum may indicate either a systemic autoimmune disease like systemic lupus erythematosus (SLE), scleroderma and polymyositis/ dermatomyositis, or an organ-specific condition like autoimmune thyroiditis and hepatitis. Identification of ANA patterns and their target antigen on the basis of variable cellular staining pattern can be correlated to specific autoimmune disease as part of diagnostic clinical immunology. Although a collection of tests are available for ANA detection, the indirect immunofluorescence (IIF)-ANA on HEp-2 cells persists to be the gold standard. ${ }^{[3]}$

According to the currently valid international consensus, the International Consensus on ANA Patterns (ICAP) [4], there are 29 recognised discrete HEp-2 cell IIF patterns that are divided into nuclear, cytoplasmic and mitotic subtypes.

HE-p substrate allows detection of antibody binding to specific intracellular targets, resulting in diverse staining patterns that are usually categorized on the basis of the cellular components recognized and the binding affinity, as reflected by the fluorescence intensity or titer. ${ }^{[5,6]}$

Immunofluorescence nuclear patterns most commonly recognized and reported by clinical laboratories include homogeneous, speckled, centromere, and nucleolar. ${ }^{[7,8,9,10,11,12,13]}$

\section{MATERIALS AND METHODS}

The present study is laboratory based descriptive type of observational study. The study was carried out in the Department of Molecular Biology, Mahatma Gandhi Medical College \&
Hospital, Jaipur (Rajasthan) during the period of July 2021 to October 2021. A total of 100 serum samples were processed for this study. Demographic data (such as age, sex, in-patient, out-patient status) of the patients were recorded.

\section{Hep2000® Fluorescent Test Procedure}

1. Reconstitute buffer (PBS): Dissolve contents of one buffer pouch in one liter of deionized or distilled water. The PBS buffer may be covered and stored at 2$10^{\circ} \mathrm{C}$ up to four weeks.

2. Sample diluent: The kit comes with a prepared sample diluent.

3. Dilute patient samples: Dilute patient samples to $1: 80$ by adding $5 \mu 1$ serum to $395 \mu 1 \quad$ sample diluent. SemiQuantitative Tittering: Make serial dilutions of screening sample (e.g. 1: 160,1:320...1:640) using sample diluent.

4. Prepare substrate slides $(25-30 \mu \mathrm{l} /$ well $)$ Remove slide from pouch and place control sera on control wells as follows: Invertcontrol dropper bottle and squeeze gently until drop is visible at the tip. Gently touch the drop to appropriate control well while avoiding direct contact of dropper tip with slide surface. Place positive $\&$ negative control as desired. Add 1 drop $(25-30 \mu \mathrm{l})$ patient sample to the numbered wells.

5. Incubate slides $(30 \pm 5$ minutes at room temperature, i.e. $18-24^{\circ} \mathrm{C}$ )

Place slide into a moist covered chamber (a petri dish with moistened paper toweling will be adequate). Incubate, with lid in place, for 30 minutes ( \pm 5 minutes $)$ at room temperature (18$\left.24^{\circ} \mathrm{C}\right)$.

6. PBS rinse: Remove slide from incubator tray and rinse briefly with PBS using a squirt bottle, Pasteur, or serological pipette. Do not squirt buffer directly on the wells

7. PBS wash: (10 minutes) Wash slide(s) 10 minutes with PBS in a slide staining dish or Coplin jar. Gentle agitation is recommended. This wash may be extended 10-30 minutes with no 
Vinita Choudhary et.al. Determination and prevalence of antinuclear antibody (ANA) patterns in autoimmune disorders in a tertiary care hospital, Jaipur.

variability in final test results. Discard PBS wash solution after use.

8. Fluorescent antibody reagent: Remove one slide at a time from PBS. Tap slide on its side against bibulous paper or paper toweling to remove excess water. Cover the wells completely using fluorescent antibody reagent; begin by placing a drop over each well. Repeat for each slide.

9. Incubate slides $(30 \pm 5$ minutes at room temperature, i.e. $18-24^{\circ} \mathrm{C}$ ) Cover the slides with an opaque incubation chamber or keep the slides in petri dishes and cover the petri dishes with a paper towel to prevent exposure to light. Allow slide to incubate 30 minutes $( \pm 5$ minutes) at room temperature (18$\left.24^{\circ} \mathrm{C}\right)$.

10. PBS rinse Remove slide from incubator tray and rinse briefly with PBS. Do not squirt buffer directly on the wells.

11. PBS wash (10 minutes) Wash slide 10 minutes with PBS in a slide staining dish or Coplin jar. Gentle agitation is recommended. This wash may be extended 10-30 minutes with no variability in final test results.

12. Mount coverslip: Remove one slide at a time from PBS. Tap slide on its side against bibulous paper or paper toweling to remove excess water.

Add 4-5 drops of semi-permanent mounting medium along midline of each slide. Then observed the slide under fluorescence microscope. ${ }^{[14]}$

\section{OBSERVATIONS AND RESULTS}

The present study is laboratory based descriptive type of observational study. The study was carried out in the Department of Molecular biology, Mahatma Gandhi Medical College \& Hospital, Jaipur, (Rajasthan) during July 2021 to October 2021.

100 Serum sample received in Department of Molecular biology, Mahatma Gandhi Medical College \& Hospital, Jaipur, (Rajasthan) were included in the study.
Table 1: Distribution of Positive and Negative Sample.

\begin{tabular}{|l|l|}
\hline Result & Number (Percentage) \\
\hline Positive & $27(27 \%)$ \\
\hline Negative & $73(73 \%)$ \\
\hline Total & $100(100 \%)$ \\
\hline
\end{tabular}

Table 1 shows the demographic comparison of patients presenting with autoimmune disorder and healthy individuals. Out of 100 sample, 27 Positive (27\%) 73 Negative $(73 \%)$

Table 2: Age group distribution

\begin{tabular}{|l|l|l|l|}
\hline Patient age bracket & No. of samples & Positive & Negative \\
\hline 1-20 years & 20 & 2 & 18 \\
\hline 20-40 years & 35 & 10 & 25 \\
\hline 40-60 years & 35 & 10 & 25 \\
\hline 60-80 years & 10 & 5 & 5 \\
\hline TOTAL & 100 & 27 & 73 \\
\hline
\end{tabular}

Table 2 exhibits the age wise distribution of included in the study. The age group most commonly affected was 20 40 years $(28 \%)$ followed by $42-60$ years (28\%) and 60-80years (14\%). 1-20(5.7\%) years.

Table 3:
\begin{tabular}{|l|l|}
\hline MALE (POSITIVE) & FEMALE (POSITIVE) \\
\hline 8 & 19 \\
\hline
\end{tabular}

Table 3 represents the ratio of ANA positive male patients $[8(29.62 \%)]$ to positive female patients [19 $(70.37 \%)]$.

\begin{tabular}{|l|l|l|l|}
\hline \multicolumn{4}{|c}{ Table 4: Prevalence of different ANA patterns: } \\
\hline $\begin{array}{l}\text { Broad } \\
\text { pattern }\end{array}$ & Subtypes & Number & $\begin{array}{l}\text { Percentage } \\
(\%)\end{array}$ \\
\hline \multirow{3}{*}{ Nuclear } & Speckled & 17 & $62.96 \%$ \\
\cline { 2 - 4 } & Nucleolar & 1 & $3.70 \%$ \\
\cline { 2 - 4 } Cytoplasmic & Homogenous & 6 & $22.22 \%$ \\
\hline Sytoplasmic & 2 & $7.40 \%$ \\
\hline sixed & $\begin{array}{l}\text { Speckled } \\
\text { SSA-Ro with }\end{array}$ & 1 & $3.70 \%$ \\
\hline
\end{tabular}

Table 4 exhibits prevalence of various ANA patterns observed in the duration of this study.

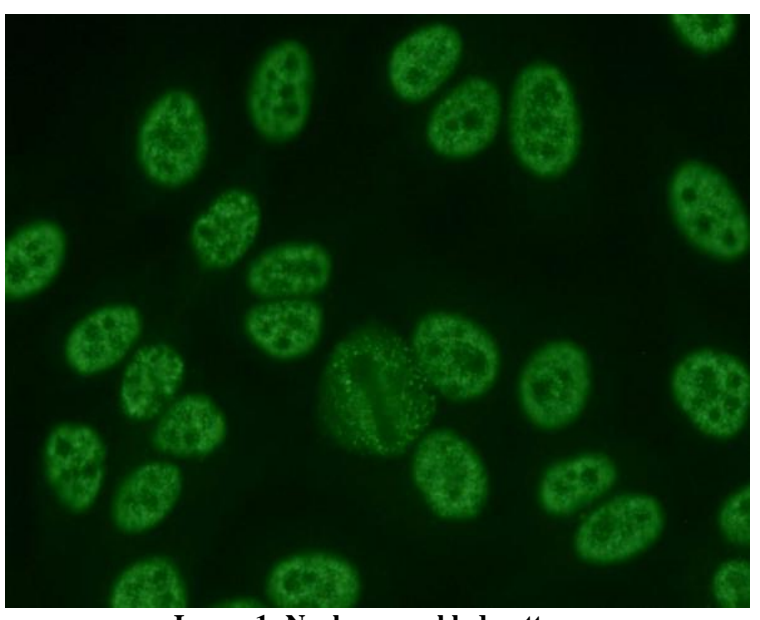

Image 1: Nuclear speckled pattern 


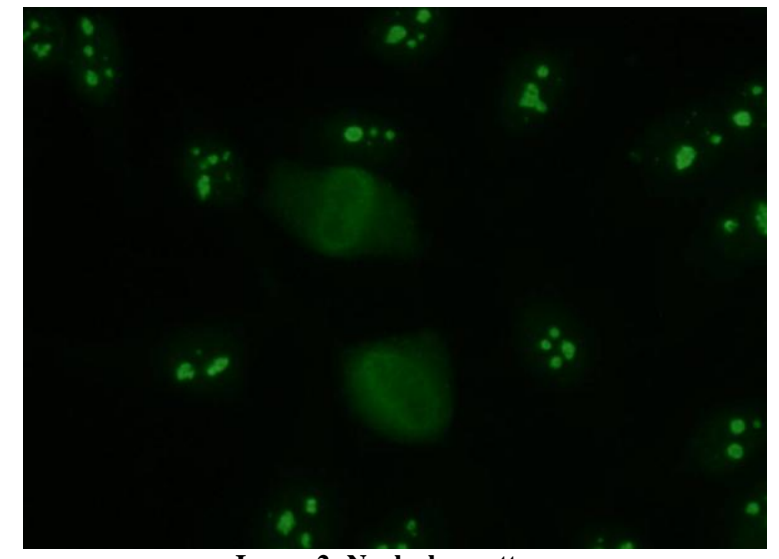

Image 2: Nucleolar pattern

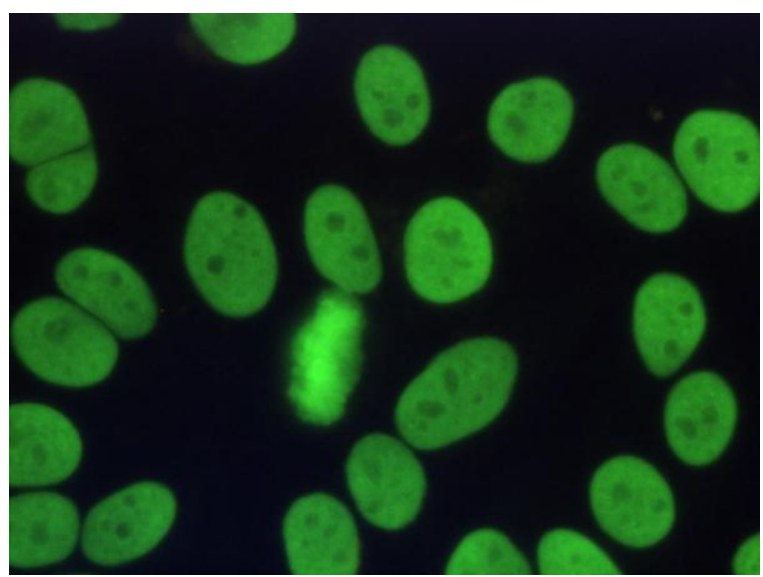

Image 3: Nuclear homogenous pattern

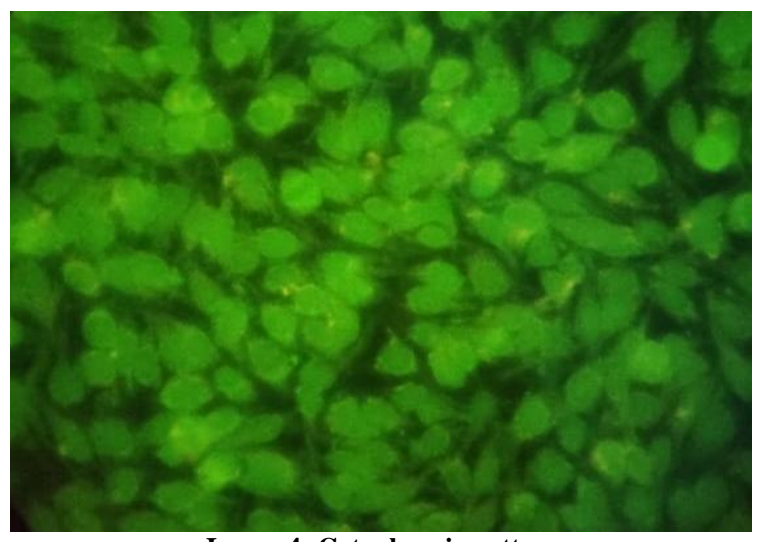

Image 4: Cytoplasmic pattern

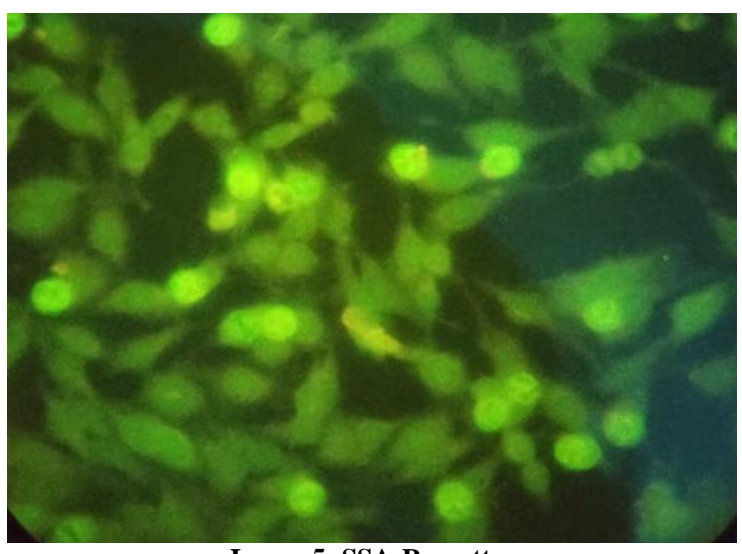

Image 5: SSA-Ro pattern

\section{DISCUSSION}

Serological testing of autoimmune disorders is a crucial diagnostic tool in a clinical setup where ANA is one among the foremost frequently requested test. With the introduction of human epithelial cell lines (Hep-2) as a substrate for the ANA test, there was a marked increase in the sensitivity, which although, often leads to false positive rates, making the interpretation for true positive arduous.

In a country like India, a laboratory needs adequate, reliable screening tests. ANA-IIF isn't only easy to perform but also cheap. Despite its subjectivity, a number of the ANA patterns are specific and are extremely helpful in clinical diagnosis. With the increase in prevalence of autoimmune disorders in India and scarce documentation of prevalence, any information about their occurrence and clinical significance might be beneficial.

The present study was a patientbased study, ANA test reports of 100 patients, evaluating the ANA positivity status with the assistance of IIF on Hep-2 cell lines was done. An ANA positivity rate of $27 \%$ was found. Other studies were undertaken in India. In Raipur Chhattisgarh by Gupta P et al the frequency of positivity was almost like in this study. ${ }^{[3]}$ In the study conducted in Chandigarh by Minz RW et al lesser positivity rate compared with present study was noted ${ }^{[15]}$. Although the results of those studies are often considered as prevalence, however, the population-based studies showed mixed results wherein Akmatov $M \mathrm{~K}$ et al in Germany and Satoh $\mathrm{M}$ et al in U.K found ANA positivity rate to be $33 \%$ and $13.8 \%$, respectively ${ }^{[16,17]}$ while Sremec Nada T et al in China and Weyand Banhuk $F$ et al within USA demonstrated much lower prevalence. [18,19] The results contradict the very fact that ANA and, in turn, autoimmunity is seen more in western countries than in India, which 
Vinita Choudhary et.al. Determination and prevalence of antinuclear antibody (ANA) patterns in autoimmune disorders in a tertiary care hospital, Jaipur.

could be a result of previous poor screening facilities. Strikingly, a regional difference is found in India itself, which can flow from climatic variation, genetic

variation, and controlling the various molecular mechanisms of autoimmunity, as explained by Atassi M $\mathrm{Z}$ et al. ${ }^{[20]}$

Table 5: Comparing studies done in India and worldwide

\begin{tabular}{|c|c|c|c|c|c|c|c|}
\hline Author & $\begin{array}{l}\text { Place of } \\
\text { study }\end{array}$ & Study design & $\begin{array}{l}\text { Sample } \\
\text { size }\end{array}$ & $\begin{array}{l}\text { ANA } \\
\text { prevalence }\end{array}$ & Age & $\begin{array}{l}\text { Female } \\
\text { predominance } \\
\text { percentage }\end{array}$ & $\begin{array}{l}\text { Most common } \\
\text { ANA pattern }\end{array}$ \\
\hline Present study & Jaipur, India & Patient-based & 100 & $27 \%$ & $40 \pm 20$ & $70.37 \%$ & Nuclear speckled \\
\hline Gupta $\mathrm{P}$ et al $^{[3]}$ & Raipur, India & Patient based & 536 & $33 \%$ & $37+18$ & $74 \%$ & Nuclear speckled \\
\hline $\begin{array}{l}\text { Weyand } \\
\text { Banhuk F et al } \\
{[19]}\end{array}$ & Brazil & Patient-based & 172 & $4.1 \%$ & -- & -- & $\begin{array}{l}\text { Nuclear } \\
\text { homogenous }\end{array}$ \\
\hline $\begin{array}{ll}\text { Akmatov } & \text { MK } \\
\text { et al }{ }^{[16]} & \end{array}$ & Germany & $\begin{array}{l}\text { Population- } \\
\text { based }\end{array}$ & 1199 & $33 \%$ & $\begin{array}{l}49(38- \\
60)\end{array}$ & Female $56.2 \%$ & Nuclear Speckled \\
\hline $\begin{array}{l}\text { Minz } R \text { W et al } \\
{[15]}\end{array}$ & $\begin{array}{l}\text { Chandigarh, } \\
\text { India }\end{array}$ & Patient-based & 650 & $18.9 \%$ & $\begin{array}{l}42(20- \\
50)\end{array}$ & Female $75.9 \%$ & Nuclear speckled \\
\hline $\begin{array}{ll}\text { Sebastian } & \text { Wet } \\
\text { al }^{[21]} & \end{array}$ & $\begin{array}{l}\text { Bangalore, } \\
\text { India }\end{array}$ & Patient-based & 5066 & $38.2 \%$ & - & - & $\begin{array}{l}\text { Nuclear } \\
\text { homogenous }\end{array}$ \\
\hline $\begin{array}{l}\text { Satoh M et al } \\
{[17]}\end{array}$ & USA & $\begin{array}{l}\text { Population- } \\
\text { base }\end{array}$ & 4754 & $13.8 \%$ & $50-59$ & $\begin{array}{lll}\text { Female } & 9.6 \% & \text { vs. } \\
17.8 \% & & \\
\end{array}$ & $\begin{array}{l}\text { Nuclear } \\
\text { homogenous }\end{array}$ \\
\hline
\end{tabular}

Female predominance within the field of autoimmunity is already established, although the explanations remain obscure. Table 5 clearly shows that each one of the studies, including this, found ANA positivity rate higher within the female patient or population group. This dominance might be attributed to estrogen as a possible modifier of autoimmunity, as stated by Parks et al ${ }^{[22]}$ the feminine to male ratio, although biased toward the previous, varies in proportion within the age groups.

The difference peaks within the young adulthood and middle age, tailing at the opposite ends (Table 3). This result complemented the results of Parks et al, stating that childbearing may play a crucial role in initial antigen stimulation or breaking tolerance to self-antigens contributing to the event of ANA. ${ }^{[22]}$

The autoimmune disorders are high within the 20 to 40 age bracket, while Satoh $M$ et al ${ }^{[17]}$ noted 40 to 60 age bracket with the very best prevalence of autoimmune disorders. This corresponds to the upper prevalence of autoimmune disorders (Table 3) and of ANA positivity within this group, as seen in the present study, with the mean age being 40 \pm 20 years. This result was almost similar to that of Guo et al in China (mean age 32 years $)^{[23]}$. A higher mean age was reported by Akmatov et al, Minz et al (49 years, 42 years and 43 years, respectively), while Satoh et al found the highest prevalence within the older age bracket. This difference might be accounted to review population composition. The ANA in older people could suggest a senile condition instead of a pathological problem. ${ }^{[16,15,17]}$

The present study showed predominance of nuclear speckled pattern. The nuclear pattern as an entire, is certainly the foremost common in the studies conducted worldwide. Among this, the nuclear homogenous and nuclear speckled patterns come to the forefront. The nuclear speckled pattern is nearly evenly distributed in all told age groups. The results of present study were almost similar to study done by Minz R W et al in Chandigarh and Gupta $P$ et al in Raipur, showing high-ANA positivity in SLE and DLE, scleroderma and rheumatoid patients ${ }^{[15,3]}$. However, the foremost common pattern related to SLE was nuclear homogenous in contrast to nuclear speckled in their studies. Minz RW et al ${ }^{[15]}$ in their article on review of diagnostics in autoimmunity stated that SLE showed positivity for both 
nuclear homogenous and nuclear speckled. It's often thought that the uncommon patterns haven't any role to play in diagnosis. ${ }^{[15,3]}$ However, the current study and studies done by Chanwit et al and Sener et al found the rare ANA patterns in significant number, and also disease conditions related to them, especially chronic hepatic conditions and carcinoma. ${ }^{[24,25]}$ The cytoplasmic patterns also are considered non disease-specific but their significance shouldn't be ignored, as stated by Chanwit et al, since they could also point to certain undetected conditions. ${ }^{[24]}$

\section{CONCLUSIONS}

Nuclear speckled was the foremost frequent pattern, few unusual patterns were also observed. An observational study is required to know not only the epidemiology of autoimmune disorders but also the predictive value of ANA IIF in clinical setup, besides considering the likelihood of taking over IIF as a screening tool for autoimmune disorders.

\section{ACKNOWLEDGEMENT}

We thank Mr. Chetan Prakash Soni (Technician; CRL), Mr. Ashok Kr. Soni (Technician; CRL), Mr. Girraj Sharma (Technician; CRL), Mr. Ajay Saini (Technician; CRL) and Mr. Akash Jain (Computer operator; CRL) for their help in conducting this study.

\section{REFERENCES}

1. Anne E, Recent Approaches To Optimize Laboratory Assessment of Antinuclear Antibodies Clinical and vaccine immunology 2017 Dec; (24):270-275.

2. P. Kern, M. Kron, and K. Hiesche Measurement of Antinuclear Antibodies: Assessment of Different Test Systems. Clin Diagno lab immunol 2000 Jan; 7(1): 72-78.

3. Gupta P, Priya R, Nanda R, Patel S, Mohapatra A Hospital-Based Insight into the Antinuclear

Antibody Patterns in
Autoimmune Disorders. J Lab Physicians .2020 Aug;12(2):115-120.

4. Chan EK, Damoiseaux J, Carballo OG, Conrad K, de Melo Cruvinel W, Francescantonio PL, Fritzler MJ, Garcia-De La Torre I, Herold M, Mimori T, Satoh M, von Mühlen CA Report of the First International Consensus on Standardized Nomenclature of Antinuclear Antibody HEp-2 Cell Patterns 2014-2015., Andrade LE Front Immunol. 2015; ( 6):412-417.

5. Agmon-Levin N, Damoiseaux J, Kallenberg C, Sack U, Witte T, Herold M, Bossuyt X, Musset L, Cervera R, Plaza-Lopez A, Dias C, Sousa MJ, Radice A, Eriksson C, Hultgren O, Viander M, Khamashta M, Regenass S, International recommendations for the assessment of autoantibodies to cellular antigens referred to as anti-nuclear antibodies. Ann Rheum Dis. 2014 Jan; 73(1): 17-23.

6. Pisetsky DS. Antinuclear antibody testing misunderstood or misbegotten? Nat Rev Rheumatol. 2017 Aug;13(8):495-502. doi: 10.1038/nrrheum.2017.74. Epub 2017 May 25. PMID: 28541299.

7. Meroni PL, Schur PH. ANA screening: an old test with new recommendations. Ann Rheum Dis. 2010; (69):1420-1422.

8. Agmon-Levin N, Damoiseaux J, Kallenberg C, Sack U, Witte T, Herold M, et al. International recommendations for the assessment of autoantibodies to cellular antigens referred to as anti-nuclear antibodies. Ann Rheum Dis. 2014; (73):1723.

9. Pisetsky DS. Antinuclear antibody testing misunderstood or misbegotten? Nat Rev Rheumatol. 2017; (13):495-502.

10. Damoiseaux J, Andrade LEC, Carballo OG, Conrad K, Francescantonio PL, Fritzler MJ, et al. Clinical relevance of HEp-2 indirect immunofluorescent patterns: the International Consensus on ANA patterns (ICAP) perspective. Ann Rheum Dis. 2019;(78):879-889.

11. Chan EK, Damoiseaux J, Carballo OG, Conrad K, de Melo Cruvinel W, Francescantonio PL, et al. Report of the First International Consensus on Standardized Nomenclature of Antinuclear Antibody HEp-2 Cell Patterns 20142015. Front Immunol. 2015; (6) :412-417.

12. Chan EK, Damoiseaux J, de Melo Cruvinel W, Carballo OG, Conrad K, 
Francescantonio PL, et al. Report on the second International Consensus on ANA Pattern (ICAP) workshop in Dresden 2015. Lupus. 2016;25:797-804.

13. Damoiseaux J, von Mühlen CA, Garcia-De La Torre I, Carballo OG, de Melo Cruvinel W, Francescantonio PL, Fritzler MJ, et al. International consensus on ANA patterns (ICAP): the bumpy road towards a consensus on reporting ANA results. Auto Immun Highlights 2016;(7):110-115.

14. Imuno Concept Fluorescent IgG ANA-Ro test system Kit insert.

15. Minz R W, Kumar $\mathrm{Y}$, Anand $\mathrm{S}$ et al. Antinuclear antibody positive autoimmune disorders in North India: an appraisal. Rheumatol Int. 2012;32 (09):2883-2888.

16. Akmatov M K, Röber N, Ahrens W et al. Anti-nuclear autoantibodies in the general German population: prevalence and lack of association with selected cardiovascular and metabolic disorders-findings of a multicenter population-based study. Arthritis Res Ther. 2017;19(01):127.

17. Satoh M, Chan EK, Ho LA, et al. Prevalence and sociodemographic correlates of antinuclear antibodies in the United States. Arthritis Rheum. 2012;64(7):23192327. doi:10.1002/art.34380.

18. Nada T, Kozmar A, Sremec J, Anić B, Batinić D Properties of Uncommon Indirect Immunofluorescence Staining Patterns Determined during Antinuclear Antibody Detection on HEp-2 Cells. J Clin Med. 2021 Sep; 10(17): 386-392.

19. Weyand Banhuk F, Corrêa Pahim B, Jorge Sandro A, and Menolli Andrade R Relationships among Antibodies against
Extractable Nuclear Antigens, Antinuclear Antibodies, and Autoimmune Diseases in a Brazilian Public Hospital. Autoimmune Dis. 2018; 985-990.

20. Atassi M Z, Casali P. Molecular mechanisms of autoimmunity. Autoimmunity. 2008;41(02):123-132.

21. Sebastian W, Roy A, Kini U, Mullick S. Correlation of antinuclear antibody immunofluorescence patterns with immune profile using line immunoassay in the Indian scenario. Indian $\mathrm{J}$ Pathol Microbiol. 2010;53(03):427-432.

22. Beeson P B. Age and sex associations of 40 autoimmune diseases. Am J Med. 1994; 96(05):457-462.

23. Guo Y P, Wang C G, Liu $X$ et al.The prevalence of antinuclear antibodies in the general population of china: a crosssectional study. Curr Ther Res Clin Exp. 2014; (76):116-119.

24. Prapinjumrune C, Prucktrakul C, Sooktonglarng T, Thongprasom K. Serum antinuclear antibody in adult Thais. Gerodontology. 2017;34(01):86-89.

25. Ag S, Afsar I. Evaluation of antinuclear antibodies by indirect immunofluorescence and line immunoassay methods 0 : four years 0 data from Turkey. APMIS. 2014; 122(12):1167-1170.

How to cite this article: Choudhary V, Sharma A, Sharma VK et.al. Determination and prevalence of antinuclear antibody (ANA) patterns in autoimmune disorders in a tertiary care hospital, Jaipur. Gal Int J Health Sci Res. 2022; 7(1): 26-32. DOI: https://doi.org/ 10.52403/gijhsr.20220104 